J. Clin. Chem. Clin. Biochem.

Vol. 26, 1988, pp. $141-146$

(C) 1988 Walter de Gruyter \& Co. Berlin - New York

\title{
Blood Glucose, Lactate, Pyruvate, Glycerol, 3-Hydroxybutyrate and Acetoacetate Measurements in Man Using a Centrifugal Analyser with a Fluorimetric Attachment
}

\author{
By J. Harrison, A.W. Hodson, A.W. Skillen, R. Stappenbeck \\ Department of Clinical Biochemistry and Metabolic Medicine, Medical School, Newcastle upon Tyne \\ L. Agius and K. G. M. M. Alberti \\ Department of Medicine, Medical School, Newcastle upon Tyne, UK
}

(Received October 20, 1987 / February 5, 1988)

\begin{abstract}
Summary: Methods are described for the analysis of glucose, lactate, pyruvate, alanine, glycerol, 3-hydroxybutyrate and acetoacetate in perchloric acid extracts of human blood, using the Cobas Bio centrifugal analyser fitted with a fluorimetric attachment. Intra-assay and inter-assay coefficients of variation ranged from 1.9 to $7.9 \%$ and from 1.0 to $7.2 \%$ respectively. Correlation coefficients ranged from 0.96 to 0.99 against established continuous-flow and manual spectrophotometric methods. All seven metabolites can be measured using a single perchloric acid extract of $20 \mu \mathrm{l}$ of blood. The versatility of the assays is such that as little as 100 pmol pyruvate, 3-hydroxybutyrate or as much as $15 \mathrm{nmol}$ glucose can be measured in the same $20 \mu 1$ extract.
\end{abstract}

In relation to budgetary control the centrifugal analyser methods are quicker, less labour intensive, and more economical with both small and large numbers of samples.

\section{Introduction}

Several automated photometric (1) and fluorimetric $(2-5)$ techniques have been developed to measure intermediary metabolites. Routinely in our laboratory blood glucose, lactate, pyruvate, alanine, glycerol and 3-hydroxybutyrate have been measured at room temperature using continuous-flow fluorimetric methods (6). Up to three different metabolites can be measured simultaneously in this system. It is relatively simple and inexpensive to operate and is capable of higher inter- and intra-assay precision with large numbers of easily prepared samples.

A major disadvantage of the continuous-flow methods is the need of an additional analytical "run" to assess sample "blanks". Other problems include the inaccuracies and tedium involved in matching large numbers of "blank" to "test" fluorescence peaks as well as measuring them. Alternative systems, which might overcome these disadvantages and yet still able to handle large numbers of samples, were considered. The most promising appeared to be a centrifugal fast analyser with a fluorescence detection accessory. A Cobas Bio with a fluorimeter attachment was acquired, appropriate methods developed and evaluated in comparison with the corresponding continuous flow methods. The main advantage of the fluorimetric centrifugal fast analyser is that the concentration of all seven metabolites can be reliably determined on a perchloric acid extract of $20 \mu \mathrm{l}$ of blood.

\section{Materials and Methods}

Lithium lactate grade L-X, sodium pyruvate Type II, lithium acetoacetate and $L$-alanine were obtained from Sigma $L t d$. (Poole, Dorset, UK), NAD, NADH, NADP, ATP, D,L-3-hydroxybutyrate (monosodium salt), lactate dehydrogenase (pig heart - Cat No 107069), hexokinase (yeast - Cat No 127817), 
L-alanine dehydrogenase (B. subtilis - Cat No 102636), glycerokinase (Candida mycoderma - Cat No 127795), 3-hydroxybutyrate dehydrogenase (Rhodopseudomonas spheroides - Cat No 737054), glycerol-3-phosphate dehydrogenase (rabbit muscle - Cat No 127752) and glucose-6-phosphate dehydrogenase (yeast - Cat No 127671) from BCL (Lewes, East Sussex, UK) with glycerol (AR), glucose $(50 \mathrm{mmol} / \mathrm{l}$ in saturated i.e. $5 \mathrm{~g} / \mathrm{l}$ benzoic acid), perchloric acid - $600 \mathrm{~g} / \mathrm{kg}(\mathrm{AR})$ and all other chemicals from BDH (Poole, UK).

\section{Sample preparation}

About $1.5-2 \mathrm{ml}$ of whole blood is added to a preweighed plastic tube containing $5 \mathrm{ml}$ of $0.77 \mathrm{~mol} / \mathrm{l}$ perchloric acid previously cooled to $0^{\circ} \mathrm{C}$. After mixing the tube is reweighed, centrifuged at $2500 \mathrm{~g}$ for $5 \mathrm{~min}$ and the protein-free supernatant removed. The dilution of the blood is determined by the weight changes measured. Alternatively $0.5 \mathrm{ml}$ whole blood may be added volumetrically to $2 \mathrm{ml} 0.77 \mathrm{~mol} / 1$ perchloric acid and the weighing omitted. Part of the supernatant is placed in an Autoanalyzer cup and the remainder stored in another plastic tube at $-20^{\circ} \mathrm{C}$. For the metabolites, other than acetoacetate, analysis of the samples in the Autoanalyzer cups is carried out immediately or they are stored at $-20^{\circ} \mathrm{C}$. Analysis for acetoacetate is carried out immediately or the samples are stored at $-70^{\circ} \mathrm{C}$ but for not longer than 3 days.

\section{Continuous flow analyses}

These are carried out essentially as described earlier (6) with $0.46 \mathrm{~mol} / 1$ perchloric acid used to prepare the standards.

\section{Acetoacetate}

A modified manual method for the determination of acetoacetate is based on that described by Williamson et al. (7). One $\mathrm{ml}$ of perchloric acid extract is put into a weighed plastic tube and reweighed. Universal indicator (BDH Cat No 21049) is added, mixed and the perchloric acid neutralized to a yellow colour with $3.5 \mathrm{~mol} / \mathrm{l}$ and $0.35 \mathrm{~mol} / 1 \mathrm{KOH}$. The tube is centrifuged and re-weighed to determine the dilution of the original sample. The supernatant is used for analysis. To determine the acetoacetate content, $500 \mu \mathrm{l}$ of the neutralized extract is added to $1 \mathrm{ml}$ of $0.42 \mathrm{mmol} / 1 \mathrm{NADH}$ in $0.1 \mathrm{~mol} / 1$ potassium phosphate buffer, $\mathrm{pH} 7.0$, and $500 \mu \mathrm{l}$ water. The absorbance is measured against a blank containing $0.21 \mathrm{mmol} / \mathrm{l} \mathrm{NADH}$ immediately at $340 \mathrm{~nm}$ using a Zeiss $\mathrm{PMQ} 3 / \mathrm{MQ} / 3$ spectrophotometer (Carl Zeiss, Woodfield Road, Welwyn Garden City, Herts., UK) and again at $30 \mathrm{~min}$, at room temperature, after adding $300 \mathrm{mU}$ of 3-hydroxybutyrate dehydrogenase to determine the decrease. Blanks are also prepared omitting the neutralized perchloric acid extract to determine enzyme interaction with the buffered coenzyme reagent. The acetoacetate content is calculated using the molar lineic absorbance of NADH of $622 \mathrm{~m}^{2} / \mathrm{mol}$. Standards are prepared using solutions of acetoacetate in $0.46 \mathrm{~mol} / \mathrm{l}$ perchloric acid over the range of $25-100 \mu \mathrm{mol} / 1$ which are treated in the same way as the perchloric acid extracts.

\section{Centrifugal analyser}

The instrument used is a Cobas Bio (Roche Products Ltd., Welwyn Garden City, UK). All the analysis program parameters are shown in table 1 . The assays for alanine, glycerol and 3-hydroxybutyrate were initial rate methods, those for acetoacetate and pyruvate end-point methods and those for glucose and lactate two-point analyses using the instruments own curvefitting programme for appropriate standards. The buffers used are the same as for the continuous-flow methods for the metabolites other than acetoacetate. Modifications, however, are made in the composition of the coenzyme/enzyme reagents as follows:

\section{Acetoacetate}

Coenzyme reagent: $500 \mu \mathrm{l} 0.75 \mathrm{~g} / \mathrm{l} \mathrm{NADH}$ in $0.3 \mathrm{~mol} / 1$ potassium phosphate buffer pH 7.4 is added to $20 \mathrm{ml}$ of the same buffer.

Enzyme reagent ("start" solution): $200 \mu \mathrm{l}$ 3-hydroxybutyrate dehydrogenase $(7.5 \mathrm{U})$ is added to $400 \mu \mathrm{l}$ water.

To set PM voltage use water as sample and ' $\alpha$ coenzyme reagent containing: $650 \mu \mathrm{l} 0.75 \mathrm{~g} / \mathrm{l} \mathrm{NADH}$ in $0.3 \mathrm{~mol} / 1$ potassium phosphate buffer pH 7.4 added to $20 \mathrm{ml}$ of the same buffer.

\section{Alanine}

Buffer: $0.04 \mathrm{~mol} / 1$ TRIS, $1 \mathrm{~mol} / 1$ hydrazine hydrate, $1.34 \mathrm{mmol} / 1$ EDTA (disodium salt) adjusted to $\mathrm{pH} 10.0$ with $10 \mathrm{~mol} / \mathrm{l}$ hy= drochloric acid.

Enzyme reagent: $20 \mathrm{mg} \mathrm{NAD}$ and $100 \mu \mathrm{l}$ alanine dehydrogenase $(12 \mathrm{U})$ in $10 \mathrm{ml} 0.1 \mathrm{~mol} / \mathrm{l}$ phosphate buffer $\mathrm{pH} 7.4$. The working reagent is prepared by adding $0.7 \mathrm{ml}$ of this solution to $8.8 \mathrm{ml}$ of the buffer. This dilution is freshly prepared for each batch of analyses and is warmed to $25^{\circ} \mathrm{C}$ before use.

To set PM voltage use top standard $(300 \mu \mathrm{mol} / \mathrm{l})$.

\section{Glucose}

Buffer: $0.1 \mathrm{~mol} / 1$ triethanolamine, $2 \mathrm{mmol} / \mathrm{l}$ magnesium chloride, adjusted to $\mathrm{pH} 8.0$ with $10 \mathrm{~mol} / 1$ hydrochloric acid.

Enzyme reagent: $32 \mathrm{mg}$ NADP, $37 \mathrm{mg}$ ATP (disodium salt), $100 \mu \mathrm{l}$ hexokinase $(140 \mathrm{U})$ and $100 \mu \mathrm{l}$ glucosè-6-phosphate dehydrogenase $(70 \mathrm{U})$ in $10 \mathrm{ml} 0.4 \mathrm{~mol} / 1$ triethanolamine buffer, $\mathrm{pH}$ 7.4.

To set PM voltage use top standard ( $3 \mathrm{mmol} / \mathrm{l})$.

\section{Glycerol}

Buffer: $0.2 \mathrm{~mol} / 1$ glycine, $1 \mathrm{~mol} / 1$ hydrazine hydrate, $10 \mathrm{mmol} / \mathrm{l}$ magnesium chloride brought to $\mathrm{pH} 9.5$ with 10 mol/1 sodium hydroxide.

Enzyme reagent: $20 \mathrm{mg}$ NAD, $20 \mathrm{mg}$ ATP (disodium salt), 50 $\mu \mathrm{l}$ glycerokinase $(21.3 \mathrm{U})$ and $100 \mu \mathrm{l}$ glycerol-3-phosphate dehydrogenase $(170 \mathrm{U})$ in $10 \mathrm{ml} 0.4 \mathrm{~mol} / \mathrm{l}$ triethanolamine buffer, $\mathrm{pH} \mathrm{7.4;0.7} \mathrm{ml} \mathrm{of} \mathrm{this} \mathrm{reagent} \mathrm{added} \mathrm{to} 8.8 \mathrm{ml}$ of the buffer for analysis. This mixture is prepared immediately before use and should be at $25^{\circ} \mathrm{C}$ when applied to the analyser.

To set PM voltage use the top standard $(120 \mu \mathrm{mol} / \mathrm{l})$.

\section{Pyruvate}

Buffer: $0.4 \mathrm{~mol} / 1$ triethanolammonium chloride, $10 \mathrm{mmol} / 1 \mathrm{di}-$ sodium EDTA adjusted to $\mathrm{pH} 7.4$ with $10 \mathrm{~mol} / \mathrm{l}$ sodium hydroxide.

Coenzyme reagent: $50 \mu \mathrm{l} 1 \mathrm{~g} / \mathrm{l} \mathrm{NADH}$ in $0.1 \mathrm{~mol} / \mathrm{l}$ phophate buffer, pH 7.4 is added to $16 \mathrm{ml}$ of the triethanolamine buffer.

Enzyme reagent ("start" solution): $50 \mu$ lactate dehydrogenase $(150 \mathrm{U})$ is added to $8 \mathrm{ml} 0.1 \mathrm{~mol} / \mathrm{l}$ phosphate buffer, $\mathrm{pH} 7.4$.

To set PM voltage use water as sample.

\section{Lactate}

Buffer: $0.5 \mathrm{~mol} / \mathrm{l}$ glycine, $0.2 \mathrm{~mol} / \mathrm{l}$ hydrazine hydrochloride, $5.4 \mathrm{mmol} / \mathrm{l}$ disodium EDTA adjusted to $\mathrm{pH} 9.6$ with $10 \mathrm{~mol} / \mathrm{l}$ sodium hydroxide.

Enzyme reagent: $50 \mathrm{mg}$ NAD and $500 \mu$ lactate dehydrogenase $(1500 \mathrm{U})$ in $5 \mathrm{ml} 0.1 \mathrm{~mol} / 1$ phosphate buffer, $\mathrm{pH} \mathrm{7.4}$.

To set PM voltage use top standard (1.2 $\mathrm{mmol} / \mathrm{l})$. 
Tab. 1. Program parameters for metabolite measurement on the Cobas Bio centrifugal analyser

\begin{tabular}{|c|c|c|c|c|c|c|c|c|}
\hline & & $\begin{array}{l}\text { Aceto- } \\
\text { acetate }\end{array}$ & Pyruvate & Glucose & Lactate & Alanine & Glycerol & $\begin{array}{l}\text { 3-Hydroxy- } \\
\text { butyrate }\end{array}$ \\
\hline & Alpha & -13 & -13 & +11 & +11 & +11 & +11 & +11 \\
\hline 1. & Units & 4 & 4 & 3 & 4 & 4 & 4 & 4 \\
\hline 2. & Calculation factor & 0 & 0 & 1000 & 1000 & 0 & 0 & 0 \\
\hline 3. & Standard 1 conc. & 25 & 10 & 0.25 & 50 & 50 & 20 & 20 \\
\hline 4. & Standard 2 conc. & 50 & 30 & 1.0 & 200 & 150 & 60 & 60 \\
\hline \multirow[t]{4}{*}{5.} & Standard 3 conc. & 100 & 60 & 1.5 & 400 & 300 & 120 & 120 \\
\hline & Standard 4 conc. & - & - & 2.0 & 600 & - & - & - \\
\hline & Standard 5 conc. & - & - & 2.5 & 900 & - & - & - \\
\hline & Standard 6 conc. & - & - & 3.0 & 1200 & - & - & - \\
\hline 6. & Limit & 0 & 70 & 0 & 0 & 0 & 200 & 200 \\
\hline 7. & Temperature, ${ }^{\circ} \mathrm{C}$ & 25 & 25 & 25 & 25 & 25 & 25 & 25 \\
\hline 8. & Assay type & 6 & 6 & 7.6 & 7.6 & 4 & 4 & 4 \\
\hline 9.* & Wavelength, nm & 340.2 & 340.2 & 340.2 & 340.2 & 340.2 & 340.2 & 340.2 \\
\hline 10. & Sample volume, $\mu \mathrm{l}$ & 20 & 10 & 5 & 5 & 10 & 10 & 20 \\
\hline 11. & Diluent volume, $\mu \mathrm{l}$ & 20 & 10 & 15 & 25 & 20 & 20 & 10 \\
\hline 12. & Reagent volume, $\mu$ l & 160 & 170 & 200 & 310 & 270 & 270 & 270 \\
\hline 13. & Incubation time, s & 300 & 300 & 300 & 300 & 0 & 0 & 0 \\
\hline 14. & Start volume, $\mu \mathrm{l}$ & 20 & 10 & 20 & 20 & 0 & 0 & 0 \\
\hline 15. & Reading time, s & 1 & 1 & 1 & 1 & 1 & 1 & 1 \\
\hline 16. & Time interval, $\mathrm{s}$ & 30 & 30 & 30 & 30 & 30 & 30 & 30 \\
\hline 17. & Number of readings & 18 & 10 & 6 & 20 & 20 & 12 & 20 \\
\hline 18. & Blanking mode & 1 & 1 & 1 & 1 & 1 & 1 & 1 \\
\hline \multirow[t]{2}{*}{19.} & Printout mode & 1 & 2 & 5.1 & 5.1 & 2 & 2 & 2 \\
\hline & PMV & 608 & 736 & 560 & 636 & 752 & 740 & 736 \\
\hline
\end{tabular}

All concentrations are in $\mu \mathrm{mol} / \mathrm{l}$ except for glucose which are in $\mathrm{mmol} / \mathrm{l}$.

* The excitation wavelength was $340 \mathrm{~nm}$ and the emission wavelength was $470 \mathrm{~nm}$. The setting 340.2 identifies that the emission filter in position No 2 is used.

\section{3-Hydroxybutyrate}

Buffer: $0.1 \mathrm{~mol} / 1$ TRIS, $1 \mathrm{~mol} / 1$ hydrazine hydrate, $2.7 \mathrm{mmol} / 1$ EDTA (disodium salt) adjusted to $\mathrm{pH} 8.5$ with $10 \mathrm{~mol} / \mathrm{l}$ hydrochloric acid.

Enzyme reagent: $10 \mathrm{mg}$ NAD and $350 \mu \mathrm{l}$ 3-hydroxybutyrate dehydrogenase $(7.5 \mathrm{U})$ in $5 \mathrm{ml} 0.1 \mathrm{~mol} / 1$ phosphate buffer, $\mathrm{pH}$ 7.4. The working reagent is prepared by adding $0.7 \mathrm{ml}$ of this solution to $8.8 \mathrm{ml}$ of the buffer.

To set PM voltage use top standard (120 $\mu \mathrm{mol} / \mathrm{l})$.

\section{Standard solutions}

Stock standards $100 \mathrm{mmol} / 1$ lithium lactate, $10 \mathrm{mmol} / \mathrm{l}$ sodium pyruvate, $10 \mathrm{mmol} / \mathrm{l}$ 3-hydroxybutyrate, $100 \mathrm{mmol} / \mathrm{l}$ glycerol, $10 \mathrm{mmol} / 1$ acetoacetate and $250 \mathrm{mmol} / 1$ alanine are prepared in deionised-distilled water and diluted to the appropriate working level with $0.46 \mathrm{~mol} / \mathrm{l}$ perchloric acid. The glucose standard is commercially available as $50 \mathrm{mmol} / 1$ in approximately $5 \mathrm{~g} / 1$ benzoic acid and is also diluted to the appropriate working level with the same perchloric acid solution. All standards are stored in a refrigerator at $4^{\circ} \mathrm{C}$. The working standards shown in table 1 are in $\mu \mathrm{mol} / \mathrm{l}$ except for glucose which is in mmol/l.

\section{Results}

The intra-assay precision for each method was assessed by filling two sample racks, one with a perchloric acid extract of blood containing a "low" concentration of the metabolite and the other with a similar extract but with a "high" concentration of the metabolite. The results are given in table 2 .
Tab. 2. Intra- and inter-assay imprecision of analyses

\begin{tabular}{|c|c|c|c|c|}
\hline & \multicolumn{2}{|c|}{$\begin{array}{l}\text { Intra-assay } \\
n=24\end{array}$} & \multicolumn{2}{|c|}{$\begin{array}{l}\text { Inter-assay } \\
\mathbf{n}=22\end{array}$} \\
\hline & $\begin{array}{l}\overline{\mathbf{x}} \\
\mu \mathrm{mol} / \mathrm{l}\end{array}$ & $\begin{array}{l}\text { CV } \\
\%\end{array}$ & $\begin{array}{l}\overline{\mathrm{x}} \\
\mu \mathrm{mol} / 1\end{array}$ & $\begin{array}{l}\text { CV } \\
\%\end{array}$ \\
\hline Alanine & $\begin{array}{r}64 \\
237\end{array}$ & $\begin{array}{l}2.3 \\
3.0\end{array}$ & $\begin{array}{r}65 \\
239\end{array}$ & $\begin{array}{l}2.7 \\
3.0\end{array}$ \\
\hline 3-Hydroxybutyrate & $\begin{array}{l}12 \\
94\end{array}$ & $\begin{array}{l}6.5 \\
2.1\end{array}$ & $\begin{array}{l}12 \\
96\end{array}$ & $\begin{array}{l}4.5 \\
1.0\end{array}$ \\
\hline Glycerol & $\begin{array}{r}20 \\
100\end{array}$ & $\begin{array}{l}7.9 \\
2.3\end{array}$ & $\begin{array}{r}20 \\
101\end{array}$ & $\begin{array}{l}5.2 \\
3.0\end{array}$ \\
\hline Glucosè & $\begin{array}{l}1100 \\
2500\end{array}$ & $\begin{array}{l}2.6 \\
5.4\end{array}$ & $\begin{array}{l}1090 \\
2540\end{array}$ & $\begin{array}{l}2.8 \\
4.2\end{array}$ \\
\hline Lactate & $\begin{array}{r}146 \\
1085\end{array}$ & $\begin{array}{l}6.0 \\
6.1\end{array}$ & $\begin{array}{l}149 \\
979\end{array}$ & $\begin{array}{l}6.1 \\
3.7\end{array}$ \\
\hline Pyruvate & $\begin{array}{l}16 \\
47\end{array}$ & $\begin{array}{l}3.5 \\
1.9\end{array}$ & $\begin{array}{r}6 \\
17\end{array}$ & $\begin{array}{r}29.8 \\
6.3\end{array}$ \\
\hline Acetoaçetate & 53 & 5.8 & - & - \\
\hline
\end{tabular}

Intra-assay variation was carried out in a single run on the analyser and inter-assay variation over a 3 week period

Inter-assay precision was assessed by measuring two pooled perchloric acid extracts on separate occasions, fresh reagents being prepared for each assay. The results are shown in table 2 . Coefficients of variation ranged from 1.0 to $7.2 \%$. 
The correlations between the results obtained by Cobas Bio and continuous-flow methods are presented in table 3. It can be seen that there was a close correlation for all metabolites with the slope of the relationship differing significantly from unity only for acetoacetate and glycerol.

Tab. 3. Correlation of metabolite results obtained with the Cobas Bio analyser compared with the continuous-flow analyser.

For the regression line $y=b x+c$ the slope and intercept are also indicated.

Acetoacetate was correlated against a manual spectrophotometric method.

\begin{tabular}{lllll}
\hline & $\begin{array}{l}\text { No of } \\
\text { ana- } \\
\text { lyses }\end{array}$ & $\begin{array}{l}\text { Correla- } \\
\text { tion coef- } \\
\text { ficient }\end{array}$ & $\begin{array}{l}\text { Slope of } \\
\text { regres- } \\
\text { sion line }\end{array}$ & $\begin{array}{l}\text { Intercept } \\
(\mu \mathrm{mol} / \mathrm{l})\end{array}$ \\
\hline Alanine & 48 & 0.99 & 0.96 & +5.9 \\
3-Hydroxybutyrate & 68 & 0.99 & 1.001 & -2.2 \\
Glycerol & 69 & 0.96 & 0.79 & +3.27 \\
Glucose & 65 & 0.99 & 1.03 & -11.0 \\
Lactate & 44 & 0.99 & 1.064 & -13.2 \\
Pyruvate & 44 & 0.99 & 1.003 & -1.25 \\
Acetoacetate & 26 & 0.97 & 1.02 & -1.2 \\
\hline
\end{tabular}

\section{Discussion}

Glucose is the most frequently measured intermediary metabolite in blood. Other intermediates of carbohydrate metabolism are also of pathophysiological and clinical interest. Apart from non-esterified fatty acids the most commonly measured are: lactate, pyruvate, 3-hydroxybutyrate, acetoacetate, glycerol and alanine. The main need to measure these metabolites currently comes from researchers seeking better understanding of diabetes and other metabolic disorders.

There are many methods available to measure these metabolites. Nearly all are enzymatic and have been shown to be rapid, sensitive and accurate. In some of those described a number of very similar assays are grouped together to measure several metabolites (5, 8 -11). Keintsch-Engel et al. describe a linked method for the ketone bodies, 3-hydroxybutyrate and acetoacetate (12). Others measure glycerol (13) and alanine (14) singly as indicators of lipolysis and gluconeogenesis from amino acids respectively. Isotope dilution offers advantages when special sampling techniques are required to measure glycerol (15), in contrast to the lack of sample preparation required to measure glucose (16) and lactate (17) by the use of enzyme electrodes.

Any advance in instrumentation tends to be applied to the measurement of metabolites. Recent examples include bioluminescence-linked methods for the measurement of glycerol (18). However, there is no best possible method because a variety of criteria, other than accuracy, must be considered before a method is chosen. The continuous-flow methods (6) which we have used previously have certain attributes which taken together make them very useful. The advantages include: the ability to handle large numbers of samples by automation, measurement of a variety of metabolites simultaneously, on the same sample by similar methods, as well as the usual requirements of precision and specificity.

The methods we have developed for the centrifugal analyser were designed to give comparable results and needed to be at least, as precise as the continuousflow methods. Efforts were primarily directed to produce economical and quick, rather than optimised methods and thus initial-rate rather than end-point or two-point, methods were chosen. Wè have previously commented on the problem of using perchloric acid extracts of blood (19). Perchloric acid interferes with enzymatic assays particularly initial rate methods. In the methods described here the small volume of perchloric acid extract used as sample reduces the concentration of perchloric acid within the assay to within the range 7 to $46 \mathrm{mmol} / \mathrm{l}$ and thus helps to reduce the inhibitory effect of the perchloric acid. The use of end-point methods for all seven metabolites would overcome the problems of perchloric acid but this would mean much longer incubation times and the use of much higher concentrations of enzymes making the assays correspondingly slower and more expensive.

Hansen \& Freier (19) have described methods for assay of the lactate, pyruvate, 3-hydroxybutyrate and acetoacetate concentrations of plasma using a spectrophotometric centrifugal fast analyser. Our fluorimetric techniques allow lower concentrations of these metabolites to be measured with improved precision. For example with 3-hydroxybutyrate the spectrophotometric analyser gave between batch imprecision of $10 \%$ at $44 \mu \mathrm{mol} / 1(20)$ whereas we found $4.5 \%$ at 12 $\mu \mathrm{mol} / \mathrm{l}$ and $1.0 \%$ at $93 \mu \mathrm{mol} / 1$.

The intra-assay precision was the worst for the estimation of lactate. This probably reflects the use of a "two-point" assay, the reaction not having gone to completion, and the instrument's own programs for data calculation from non-linear standard curves. Only the glucose and lactate assays require these programs, the other assays providing linear standard curves. Inter-assay precision for most analyses was excellent. Inter-assay precision studies were not carried out for acetoacetate analysis because of the instability of this metabolite in low concentration especially in solutions containing even small amounts of 
protein. Overall precision was at least as good as obtained by other methods and at the higher concentrations much better.

Excellent correlation was obtained between the values obtained with the continuous flow and centrifugal fast analysers and apart from the acetoacetate and glycerol assays the slope of the regression line was close to unity. For acetoacetate the explanation of this deviation may lie in the inherent instability of this metabolite but for glycerol may lie in the calculation procedure. Glycerol is analysed using a ratereaction method but the calibration curve shows significant curvature suggesting sub-optimal conditions. In relation to this assay it is important that the enzyme reagent is freshly prepared and pre-warmed to $25^{\circ} \mathrm{C}$ before use.

Regression analysis showed positive intercepts for alanine and glycerol but these were small in relation to the levels usually found in blood. The negative intercept for the lactate assay is also small in relation to usual blood levels. The reason for these intercepts is unclear but again may be due to the calculation procedures used by the microprocessor in the Cobas Bio to calculate the substrate concentrations. For acetoacetate the correlation against a manual spectrophotometric method (7) as a satisfactory continuous-flow method is unavailable.

One disadvantage of the continuous-flow methods is the need for two autoanalyser "runs" to be made: one to determine the concentration of the substrate present, and the other to determine the instrinsic or "blank" fluorescence in the blood extracts. This "blank" can range from the barely detectable to amounts above the top standard in the range used. Another disadvantage with the continuous-flow methods is the need to draw calibration graphs and compare large numbers of peaks. which is necessarily timeconsuming and a notorious source of error. The tedium of the analyst and the calculation errors can be very much reduced by using an appropriate program and a microcomputer to process the fluorimeter data (20). A major advantage of the Cobas Bio analyser

\section{References}

1. Asrow, G. (1969) Anal Biochem 28, 130-137.

2. Antonis, A., Clark, M. \& Pilkington, T. R. E. (1966) J. Lab. Clin. Med. 68, 340-346.

3. Cramp, D. G. (1970) J. Med. Lab. Technol. 27, 359-365.

4. Lesse, H. J. \& Bronk, J. R. (1972) Anal. Biochem. 45, $211-216$.

5. Ozand, P. T., Hawkins, R. L., Collins, R. M. Jr., Tildon, J. T. \& Cornblath, M. (1975) Biochem. Med. 14, 170-183.

6. Lloyd, B., Burrin, J. M., Smyth, P. \& Alberti, K. G. M. M. (1978) Clin. Chem. 24, 1724-1729. is that the instrument automatically takes sample blanks into account thus eliminating "blank" runs. This results in a very considerable saving of time and reagents so that analysis of batches of all six metabolites takes less than half the time used with the continuous-flow methods. Measuring acetoacetate by the Cobas Bio analyser is very much quicker than the manual or automated spectrophotometric methods previously described $(7-12)$.

The fluorimetric methods we have described are extremely sensitive and readily assay as little as 100 pmol of pyruvate, $200 \mathrm{pmol}$ of 3-hydroxybutyrate and $400 \mathrm{pmol}$ of glycerol. There is, generally, enough glucose and lactate in our samples for much less sensitive methods to be used. However, to eliminate an extra source of error the methods have been designed so that the whole group of analyses can be done without further dilution of the intial perchloric acid extract. The volume of perchloric acid extract needed to carry out all seven analyses is about $100 \mu \mathrm{l}$ which represents $20 \mu \mathrm{l}$ or less of blood and is much less than that required for the continuous-flow system. By using less sample, reagent costs including particularly expensive enzyme preparations is approximately one third of those needed for the continuousflow system. Operation of the Cobas Bio, however, does require the use of disposable rotors and the cost of these makes analysis only about $20 \%$ less expensive overall than the continuous-flow system. The use of small samples entails an increased possibility that endpoint analyses are feasible.

With the Cobas Bio, a change from one metabolite method to another can be made very quickly. Therefore it is possible to analyse small numbers of samples for a variety of different metabolites quickly, whereas the continuous-flow system is most economical of time and reagents when relatively long "runs" are made. Thus the Cobas Bio allows greater flexibility in the choice of the methods available as well as being more user-friendly. In practice we have found that analysts become proficient in the use of the Cobas Bio in a very much shorter time than that necessary with the continuous-flow system.

7. Williamson, D. H., Mellanby, J. \& Krebs, H. A. (1962) Biochem. J. 82, 90-98.

8. Cuthbert, C. \& Alberti, K. G. M. M. (1978) Clin. Chim. Acta 90, 179-186.

9. Maughan, R. J. (1982) Clin. Chim. Acta 122, 231-240.

10. Li, P. K., Lee, S. T., Macgillivray, M. H., Schaefer, P. A. \& Siegel, J. H. (1980) Clin. Chem. 26, 1713-1717.

11. Weicker, H., Hagele, H. \& Kornes, B. (1984) Int. J. Sports Med. 5, 47-54. 
12. Kientsch, R. I., Siess, E. A. \& Wieland, O. H. (1982) Anal. Biochem. 123, 270-275.

13. Huber, C. T., Duckworth, W. C. \& Solomon, S. S. (1978) Anal. Biochem. 85, 239-250.

14. Lowry, O. H. \& Passoreau, J. V. (1972) In: "A flexible system of enzymatic analysis" 1st ed., Academic Press, New York and London p. 149.

15. Bell, J. D., Buxton, I. L. O. \& Brunton, L. L. (1984) Anal. Biochem. 139, 305-308.
16. Smith, P. A., Goldfinch, M. E., Sheldon, W. L. \& Hodson, A. W. (1985) Report of the Scientific \& Technical Branch, Department of Health and Social Security, London, May.

17. Clark, L. C., Noyes, L. K., Grooms, T. A. \& Moore, M. S. (1984) Critical Care Med. 12, $461=464$.

18. Lave, J. T. (1984) Anal. Biochem. 139, 510-515.

19. Hansen, J. L. \& Freier, E. F. (1978) Clin. Chem. 24, 475-479.

20. Hetherington, C. S., Keir, M., Stappénbeck, R., Simm, A., Brigham, L. L., Skillen, A. W. \& Hodson A. W. (1986) J. Automatic Chem. 8, 49-55.

Dr. A.W. Skillen

Dept. of Clinical Biochemistry

and Metabolic Medicine

Medical School

Newcastle upon Tyne

UK 